by the Agreement is of great help in reaching its goals. This mechanism, although still being created, should result into the full-functioning bodies under the Agreement for its better and faster execution. The author further gives the characteristics to these institutions of cooperation and proves the effectiveness of this structure to support and increase in effectiveness of cooperation that would lead to successful implementation. At the same time, the special attention is drawn to additional special conditions needed on the side of Ukraine to make the Agreement work, in particular political will and capabilities of state servants. Although the will is declared and additional bodies, such as Governmental office on European integration, were formed the process is lagging behind. The author believes that civil society that demonstrated its power during recent years would closely monitor integration process and may become a key success factor because the reforms are still aimed at increasing the living standards, modernization of the country, democratic stability and economic growth.

Key words: institutional structure, cooperation bodies, association agreement, the European Union, civil society.

DOI: 10.36695/2219-5521.2.2019.37

УДК 341.63

\title{
В.Н. ПЕТРИНА
}

Володимир Нестерович Петрина, кандидат юридичних наук, доцент Національної академії внутрішніх справ*

ORCID: 0000-0002-1093-7089

\section{ТЕРМІНОЛОГІЧНІ ПРОБЛЕМИ В УКРАЇНСЬКОМУ ЗАКОНОДАВСТВІ ПРО МІЖНАРОДНИЙ КОМЕРЦІЙНИЙ АРБІТРАЖ}

Постановка проблеми. Арбітраж $є$ найбільш поширеним шляхом вирішення спорів, що виникають у рамках міжнародних комерційних відносин. У цьому зв'язку важливо, щоб норми, які регулюють відносини у сфері міжнародного комерційного арбітражу, в усіх країнах світу були гармонізовані для того, щоб суб'єкти міжнародних комерційних відносин будь-яких країн, вдаючись до арбітражу для вирішення спорів між ними, однаково розуміли ці норми в силу їх уніфікованості.

Необхідність гармонізації усіма країнами світу законодавства про міжнародний комерційний арбітраж визнана в документах Організації Об'єднаних Націй, зокрема в резолюції Генеральної Асамблеї ООН № 40/72 від 11 грудня 1985 р., якою було схвалено Типовий закон про міжнародний комерційний арбітраж (англ. UNCITRAL Model Law on International Commercial Arbitration), розроблений Комісією ООН з права міжнародної торгівлі (UNCITRAL), та рекомендовано усім країнам-членам ООН врахувати положення цього типового закону з метою уніфікації законодавства цих країн з міжнародного комерційного арбітражу1.

На підставі вищезазначеної резолюції Генеральної Асамблеї ООН практично кожна країна-член $\mathrm{OOH}$ прийняла свій власний закон про міжнародний комерційний арбітраж, в основу якого було покладено вищезгаданий Типовий закон Юнсітрал про міжнародний комерційний арбітраж (далі - Типовий Закон Юнсітрал). Україна 24 лютого 1994 р. також прийняла такий закон, а саме Закон України «Про міжнародний комерційний арбітраж» (далі - ЗУ про МКА), зазначивши в його преамбулі, що «цей Закон ... враховує положення про такий арбітраж, які є в міжнародних договорах Украйни, а також в типовому законі, прийнятому в 1985 році Комісією ООН з права міжнародної торгівлі і схваленому Генеральною Асамблеєю ООН для можливого використання державами у своєму законодавстві»².

Проте, прийнявши ЗУ про МКА, Україна все ж таки не достатньою мірою досягла цілей гармонізації свого законодавства про міжнародний комерційний арбітраж з нормами міжнародного права. Норми ЗУ про МКА часом суттєво відрізняються від положень, передбачених Типовим Законом Юнсітрал, і головним чином це стосується термінології, що застосовується в ЗУ про МКА. Навіть саме поняття «арбітраж» в ЗУ про МКА концептуально відрізняється від поняття «арбітраж» (англ. arbitration), що застосовується в актах міжнародного права та права економічно розвинутих країн.

Такий стан речей в українському законодавстві про міжнародний комерційний арбітраж, яке $є$ частиною законодавства України із врегулювання господарських спорів, призводить до того, що Україна займає нижні сходинки у відповідних світових рейтингах. Так, наприклад, за таким показником, як «efficiency of legal framework in settling disputes» (що українською можна перекласти, як ефективність/якість/точність нормативно-правових актів, спрямованих на вирішення спорів) у Звіті про глобальну конкурентоспроможність (англ. the Global Competitiveness Report) за 2018 р. Україна посіла 103 місце із 140 країн, що досліджувалися³ До того ж, завдяки цій проблемі українські юристи, що набувають знань про міжнародний комерційний арбітраж виключно з українських (та російських) джерел, зазвичай не цілком адекватно розуміють суть та механізм міжнародного комерційного арбітражу, що відбувається поза межами України та СНД.

(C) В.Н. Петрина, 2019

* Volodymyr Petryna, Ph.D. in Law, Associate professor of the National Academy of Internal Affairs 
Аналіз останніх досліджень і публікацій. Темі міжнародного комерційного арбітражу присвячені роботи низки українських правознавців, серед яких К. Вітман, А. Довгерт, В. Кисіль, В. Комаров, В. Луць, О. Переверзєва, І. Побірченко, М. Приходько, І. Проценко, Ю. Рилач, А. Цірат, Г. Цірат, Ю. Шемшученко та інші. Проте ці роботи носять головним чином описовий характер, ознайомлюючи (з різним ступенем деталізації) читачів з українською концепцією міжнародного комерційного арбітражу, з нормами українського законодавства про міжнародний комерційний арбітраж та джерелами міжнародного права у цій сфері. В українській літературі не проводився аналіз на відповідність понять і термінів, що використовуються в українському законодавстві про міжнародний комерційний арбітраж, поняттям і термінам, які використовуються у відповідних актах міжнародного права.

Формулювання мети статті. 3 огляду на вищезазначене дослідження проблем гармонізації права України у сфері міжнародного комерційного арбітражу з міжнародним правом та правом економічно розвинутих країн $€$ для української юридичної науки досить актуальною задачею. У цьому зв'язку метою даної статті є з'ясування відмінностей в термінології та понятійному апараті, що існують між українським правом (зокрема ЗУ про МКА), з одного боку, та міжнародним правом і правом економічно розвинутих країн (зокрема Типовим Законом Юнсітрал), з іншого боку. Стаття також має на меті визначення причин, що породили ці відмінності, а також формування пропозицій щодо внесення змін до законодавства України, які б усунули ці відмінності і більшою мірою гармонізували право України в цій сфері з міжнародним правом та правом економічно розвинутих країн.

Виклад основного матеріалу. Головна причина, яка призводить до відмінностей між правом України та міжнародним правом і правом економічно розвинутих країн в даній сфері, і яка відчутно далася взнаки при прийнятті ЗУ про МКА, на нашу думку, полягає в тому, що українське право до цього часу послуговується концепціями і термінологією радянського та російського права, а також перекладами відповідних міжнародних документів у сфері міжнародного комерційного арбітражу, підігнаними під радянські та російські концепції та термінологію (про термінологічну плутанину, що існує в російському праві в сфері міжнародного комерційного арбітражу, можна прочитати в статті Т. Некрасової «Ошибки и ловушки в юридическом переводе: арбитраж», що була опублікована в російському журналі для професійних перекладачів «Мосты» № 1 (17) 2008)4. Притому, застосовуючи зазначені концепції та термінологію в українському законодавстві про міжнародний комерційний арбітраж, український законодавець не зважив на те, що радянські та російські концепції і термінологія, що стосується арбітражу, часто на концептуальному рівні суперечать положенням не тільки міжнародного, а й сучасного українського права.

Для розуміння витоків термінологічних проблем сучасного українського законодавства про міжнародний комерційний арбітраж необхідно зробити певний екскурс в історію формування поняття «арбітраж» на теренах України.

У цьому зв'язку треба нагадати, що в СРСР, де існувала адміністративно-командна економіка і де підприємницька (комерційна) діяльність вважалася злочином, суди не мали права розглядати господарські спори. Для розгляду господарських спорів ще в тридцяті роки минулого століття в СРСР були створені органи державної виконавчої влади, які в СРСР назвали державними арбітражами. При цьому арбітражем в СРСР стали називати і орган, завданням якого було вирішувати господарські спори, і процедуру (механізм, порядок) вирішення господарських спорів, і конкретний склад державних арбітрів, що вирішували певний спір5.

Термін «арбітраж» для назви такого органу було запозичено із права країн з ринковою економікою, де цей термін означав альтернативний державному судочинству спосіб вирішення комерційних спорів за допомогою приватної особи (осіб) в якості посередника. Таким чином, те, що створили і назвали «арбітражем» в СРСР, принципово відрізнялося від того, що споконвіку називалося «арбітражем» (англ. arbitration) в країнах з ринковою економікою.

Створивши в СРСР такого роду арбітраж, для того, щоб не плутати цей арбітраж зі справжнім (комерційним) арбітражем (що існував в країнах з ринковою економікою) і структурами, що його здійснювали, в радянському праві (а за ним в російському і українському праві) справжній арбітраж і структури, що його здійснювали, стали називати третейським судом. Тут треба зазначити, що поза межами СРСР (в країнах 3 ринковою економікою) спосіб вирішення комерційних спорів за допомогою посередника без участі держави продовжував і далі називатися «арбітражем» (англ. arbitration), а конкретний склад арбітрів, що вирішували певний спір, як завжди називався «арбітражним трибуналом» (англ. arbitral tribunal).

Після розпаду СРСР і в Росії, і в Україні для вирішення господарських спорів замість державних арбітражів, як органів державної виконавчої влади, були створені такі органи державної судової влади, які називалися арбітражними судами.

Треба зауважити, що ситуація з існуванням на теренах СРСР державного арбітражу, а в пострадянських країнах - державних арбітражних судів, з точки зору міжнародного права та права країн з ринковою економікою носила, можна сказати, абсурдний характер, бо сама ідея арбітражу, як суспільного явища (що виникло багато віків назад і зовсім не в СРСР, Росії чи Україні), базується саме на тому, що арбітраж (англ. arbitration) $є$ способом вирішення спорів без участі держави та ії судів 6 . До цього треба додати, що у зв'язку із перейменуванням в радянському і пострадянському праві комерційного арбітражу в третейський суд та у зв'язку зі створенням в пострадянській Росії і Україні державних арбітражних судів в Україні існувала певний час (а в Росії існує до цього часу) така парадоксальна ситуація, коли, говорячи українськими термінами, господарське судочинство здійснювалось арбітражними судами, а арбітраж здійснювався третейськими судами. 
21 червня 2001 р. в Україні не стало державних арбітражних судів: вони були перетворені на господарські суди (в Росії державні арбітражні суди продовжують існувати до цього часу). 11 травня 2004 р. в Україні було прийнято Закон України «Про третейські суди» і норми ЗУ про МКА відразу ж стали конфліктувати 3 нормами Закону України «Про третейські суди», як це пояснюється далі в цій статті.

Серед проблем, які породжені в українському праві, спрямованому на регулювання міжнародного комерційного арбітражу, вищезазначеною причиною, можна виділити наступні:

1) надання терміну «арбітраж» в українському законодавстві іншого значення, ніж цей термін (англ. arbitration) має в актах міжнародного права та в законодавстві економічно розвинутих країн.

Не зважаючи на те, що в Україні вже не існують такі органи, як державний арбітраж чи державний арбітражний суд, в українському праві услід за радянським правом (та всупереч міжнародному праву та праву економічно розвинутих країн) надалі стверджується, що терміном «арбітраж» «позначають три взаємопов'язаних поняття, які відображують різні аспекти иього явища: по-перше, під міжнародним комерційним арбітражем розуміють орган, завданням якого є вирішення міжнародних комериійних спорів; подруге, ией термін означає процедуру (механізм, порядок) вирімення спорів; по-третє, міжнародним комерційним арбітражем називають конкретний склад арбітражу, що вирімуе певний спір»7.

Грунтуючись на вищезазначеному розумінні терміна «арбітраж», українські законодавці дали в ст. 2 ЗУ про МКА таке визначення даного терміна: «арбітраж - ие будь-який арбітраж (третейський суд) незалежно від того, чи утворюється він спеціально для розгляду окремої справи, чи здійснюється постійно діючою арбітражною установою...»․ Таким чином, арбітраж у зазначеному законі визначається як третейський суд, тобто певна організаційна структура.

Проте в міжнародному праві та праві економічно розвинутих країн, як уже зазначалося, під арбітражем розуміється виключно «спосіб вирішення спорів»9, що являє собою «приватний проиес, в якому сторони спору погоджуються на те, щоб одна чи кілька фізичних осіб могли, розглянувши докази і ознайомивщись $з$ аргументами сторін, прийняти рішення з врегулювання певного спору»10. В актах міжнародного права та права економічно розвинутих країн термін «арбітраж» (англ. arbitration) ніде і ніколи не вживається для позначення органу, завданням якого $\epsilon$ вирішення міжнародних комерційних спорів, або/та для позначення конкретного складу арбітрів, що вирішують певний спір (на відміну від того, як це робилося в радянських та надалі робиться в українських та російських джерелах). Разом із тим в актах міжнародного права та права економічно розвинутих країн для позначення відповідної установи, завданням якої є адміністрування арбітражу, вживається термін «арбітражна установа» (англ. arbitral institution) ${ }^{11}$, а для позначення конкретного складу арбітрів, що вирішують певний спір, вживається термін «арбітражний трибунал» (англ. arbitral tribu$\mathrm{nal})^{12}$. Також треба наголосити, що ніде і ніколи в актах міжнародного права та права економічно розвинутих країн терміни «арбітраж» (англ. arbitration), «арбітражна установа» (англ. arbitral institution) та «арбітражний трибунал» (англ. arbitral tribunal) не вживаються як синоніми і не підміняють один одного;

2) використання в украйнському законодавстві різних термінів (а саме термінів «третейський суд» та «арбітражний суд») для позначення одного і того самого поняття, що в актах міжнародного права та права економічно розвинутих країн завжди позначасться тільки одним терміном - «arbitral tribunal» (українською - арбітражний трибунал).

Так, наприклад в п. 3 ст. 33 ЗУ про МКА зазначено наступне: «Якщо сторони не домовились про інше, будь-яка із сторін, повідомивши про ие іншу сторону, може протягом 30 днів після отримання арбітражного рішення просити третейський суд винести додаткове рімення стосовно вимог, які були заявлені в ході арбітражного розгляду, проте не були відображені в ріменні. Арбітражний суд, якщо він визнає прохання виправданим, повинен протягом 60 днів винести додаткове рімення»13.

Таким чином, ми бачимо, що в ЗУ про МКА одночасно використовуються терміни «третейський суд» $\mathrm{i}$ «арбітражний суд». При цьому ніде в даному законі не пояснюється, чи мається на увазі один і той же суд, чи йдеться про якісь різні суди. Тому читачу ЗУ про МКА залишається тільки гадати.

Разом із тим, якщо ми звернемось до, так би мовити, першоджерела, тобто до оригіналу Типового Закону Юнсітрал англійською мовою (який мав би лягти в основу ЗУ про МКА), то побачимо, що там у ст. 33, яка містить аналогічні норми, для позначення і того, що в ст. 33 ЗУ про МКА називається третейським судом, і того, що в ст. 33 ЗУ про МКА називається арбітражним судом, використовується один і той самий термін «arbitral tribunal» ${ }^{4}$ (українською - арбітражний трибунал). При цьому в Типовому Законі Юнсітрал арбітражний трибунал визначається як один арбітр або група арбітрів 15 ;

3) позначення одним терміном, а саме терміном «третейський суд», різних понять, які в міжнародному праві позначаються відповідно різними термінами, а саме термінами «arbitration» (українською - арбітраж) та «arbitral tribunal» (українською - арбітражний трибунал).

Так, наприклад, в преамбулі та в першому абзаці частини першої ст. 2 ЗУ про МКА терміном «третейський суд» позначається поняття, яке відповідно в преамбулі та в першому абзаці частини першої ст. 2 Типового Закону Юнсітрал позначено терміном «arbitration» (українською - арбітраж). Термін «arbitration» (українською - арбітраж») в міжнародному праві та праві економічно розвинутих країн означає виключно «спосіб вирішення спорів із залученням однієї або більшої кількості нейтральних третіх осіб, які зазвичай визначаються за домовленістю сторонами спору та чиє рімення є обов'язковим до виконання» ${ }^{16}$.

Водночас у ст. ст. $13,16,17,19,20,22-29,30-4,36$ ЗУ про МКА терміном «третейський суд» позначається поняття, яке у відповідних статтях Типового Закону Юнсітрал позначено терміном «arbitral tribunal» 
(українською - арбітражний трибунал). Термін «arbitral tribunal» (українською - арбітражний трибунал) в міжнародному праві та праві економічно розвинутих країн означає одного або кількох арбітрів, які призначені для вирішення спору шляхом арбітражу17;

4) визначення в Законі України «Про міжнародний комерційний арбітраж» термінів «арбітраж» та «третейський суд» як синонімів, але фактичне використання в даному законі цих термінів для позначення різних явищ.

Як уже зазначалося, українська правова доктрина всупереч міжнародному праву надалі послуговується радянською концепцією арбітражу, згідно з якою терміном «арбітраж» позначається і орган, завданням якого $\epsilon$ вирішувати господарські спори, і процедура (механізм, порядок) вирішення господарських спорів, і конкретний склад арбітрів, що вирішують певний спір ${ }^{18}$.

В силу такого, так би мовити, радянського розуміння поняття арбітраж при прийнятті ЗУ про МКА українські законодавці відхились від модельного тексту Типового Закону Юнсітрал, запропонованого $\mathrm{OOH}, \mathrm{i}$ додали до цього типового тексту дещо від себе, намагаючись зробити так, щоб ЗУ про МКА відповідав радянській/українській концепції арбітражу. Таким чином, і в преамбулі, і в частині першій ст. 2 ЗУ про МКА до слова «арбітраж» (англ. arbitration), яке використовуються у відповідних місцях в оригіналі Типового Закону Юнсітрал англійською мовою19, були в дужках добавлені слова «третейський суд». Так, в преамбулі ЗУ про МКА було зазначено: «Цей Закон виходить з визнання корисності арбітражу (третейського суду).... ${ }^{20}$. В абзаці першому частини першої ст. 2 ЗУ про МКА було зазначено: «"арбітраж” - будь-який арбітраж (третейський суд)...»21.

У такий спосіб у ЗУ про МКА було зафіксовано, що терміни «арбітраж» та «третейський суд» є синонімами, тобто словами різними за звучанням і написанням, але які мають тотожне лексичне значення. Проте, давши таке визначення в преамбулі та в ст. 2 ЗУ про МКА, законодавець надалі в цьому законі не вживає терміни «арбітраж» та «третейський суд» як синоніми, а, відповідно до Типового Закону Юнсітрал, позначає цими термінами різні явища. А саме: терміном «арбітраж» позначається процедура (механізм, порядок) вирішення спорів, а терміном «третейський суд» - конкретний склад арбітрів, що вирішують певний спір. Так, наприклад, у ст. 20 ЗУ про МКА зазначається, що «....місие арбітражу визначається третейським судом»22;

5) використання в украйнському законодавстві про міжнародний комерційний арбітраж терміна «третейський суд» всупереч концепції третейського суду, що існує в сучасному українському праві.

Термін «третейський суд» широко вживається в ЗУ про МКА, зокрема, в преамбулі, ст. ст. 1, 2, 13, 16, $17,19,20,22-29,30-34,36$ та в назві Розділу III ЗУ про МКА. Цим терміном в ЗУ про МКА позначаються часом різні поняття, але які беззаперечно стосуються тих чи інших аспектів міжнародного комерційного арбітражу.

У цьому зв’язку треба звернути увагу на те, що в Україні існує Закон України «Про третейські суди». В основу концепції третейського суду покладені наступні положення цього закону:

- «третейський суд - недержавний незалежний орган, щьо утворюється за угодою або відповідним ріменням заінтересованих фізичних та/або юридичних осіб у порядку, встановленому цим Законом, для вирішення спорів, щео виникають із цивільних та господарських правовідносин» (ст. 2) 23;

- «третейський суддя - фізична особа, призначена чи обрана сторонами у погодженому сторонами порядку або призначена чи обрана відповідно до иього Закону для вирішення спорів у третейському суді» (ст. 2) 24 .

- «третейські суди в порядку, передбаченому иии Законом, можуть розглядати будь-які справи, щзо виникають із иивільних та господарських правовідносин, за винятком: ... 12) справ, коли хоча б одна із сторін спору є нерезидентом Украӥни» (ст. 6) ${ }^{25}$.

Таким чином, із вищенаведеного ми можемо бачити, що згідно з українською концепцією третейського суду третейський суд складається 3 третейських суддів (а не арбітрів, як передбачено в ЗУ про МКА), а головне, що третейський суд не може розглядати справи в порядку міжнародного комерційного арбітражу. Адже міжнародний комерційний арбітраж, так би мовити, за визначенням передбачає участь у справі нерезидентів України, а згідно з п. 12 частини першої ст. 6 Закону України «Про третейські суди» третейський суд не може розглядати будь-які справи, коли хоча б одна із сторін спору є нерезидентом Україниㄹ.

У цьому зв'язку ми можемо констатувати, що значення, в якому використовується термін «третейський суд» в ЗУ про МКА, суперечить концепції третейського суду, визначеній у Законі України «Про третейські суди».

У зв'язку із колізією норм ЗУ про МКА та Закону України «Про третейські суди» щодо правового статусу третейських судів не зайвим буде нагадати загальні правила подолання колізій між нормами права, згідно $з$ якими: а) «при розбіжності між загальним і спещіальним нормативно-правовим актом перевага надається спеціальному, якщо він не скасований виданим пізніше загальним актом» 27; б) «у разі існування неузгодженості між нормами, виданими одним і тим самим нормотворчим органом, застосовується акт, виданий пізніше, навіть якще прийнятий раніше акт не втратив своєї чинності» 28 . У цьому зв'язку треба зазначити, що Закон України «Про третейські суди», по-перше, є спеціальним законом у сфері регулювання суспільних відносин з «утворення та діяльності третейських судів в Україні» (див. ст. 1 даного Закону)29, а, по-друге, був прийнятий пізніше, ніж ЗУ про МКА. Тому за відповідними правилами вирішення колізій при визначенні правового статусу третейських судів мають застосовуватися норми Закону України «Про третейські суди», а не ЗУ про МКА. 
В якості ремарки треба зауважити, що положення ст. 1 Закону України «Про третейські суди» про те, що «дія иьього Закону не поширюється на міжнародний комериійний арбітраж»» ${ }^{30}$, не знімає проблему колізії норм ЗУ про МКА та Закону України «Про третейські суди» щодо правового статусу третейських судів в Україні, бо норми ЗУ про МКА, без усякого сумніву, спрямовано на визначення правового статусу третейських судів.

Підсумовуючи розгляд термінологічних проблем законодавства України про міжнародний комерційний арбітраж, варто звернути увагу на те, що згідно з положеннями ст. ст. 1, 8, 9, 35 і 36 ЗУ про МКА та положеннями Конвенції про визнання та виконання іноземних арбітражних рішень (англ. Convention on the Recognition and Enforcement of Foreign Arbitral Awards ${ }^{31}$ ) питання про вирішення колізії між нормами про міжнародний комерційний арбітраж ЗУ про МКА та актів міжнародного права може постати перед компетентними органами тієї чи іншої юрисдикції. У такому випадку зазначена колізія буде вирішуватись за загальним правилом, яке застосовується практично в усіх країнах світу і яке закріплене в низці українських законодавчих актів (зокрема, у ст. 19 Закону України «Про міжнародні договори України», у ст. 3 Закону України «Про міжнародне приватне право» та в усіх процесуальних кодексах України). Згідно з цим загальним правилом «якщо міжнародним договором України, який набрав чинності в установленому порядку, встановлено інші правила, ніж ті, щзо передбачені у відповідному акті законодавства України, то застосовуються правила міжнародного договору» ${ }^{32}$. Тому, якщо вищезазначені українські концепції та терміни, запозичені із радянського права і закріплені в ЗУ про МКА, почнуть конкурувати у відповідних процесах 3 нормами міжнародного права, то вони, звісно, програють в цій конкуренції, ну, а українське право, що досі послуговується цими пострадянськими концепціями та термінами, тільки ще міцніше закріпиться на нижніх сходинках відповідних міжнародних рейтингів.

Висновки. Гармонізувати норми права України про міжнародний комерційний арбітраж 3 нормами міжнародного права та права економічно розвинутих країн у цій сфері, на нашу думку, можна в наступний спосіб:

а) видалити термін «третейський суд» (у відповідних відмінках) в преамбулі, п. 5 ст. 1, абзаці другому ст. 2 Закону України «Про міжнародний комерційний арбітраж» і використовувати там тільки термін «арбітраж» для позначення відповідного способу вирішення міжнародних комерційних спорів;

б) видалити термін «третейський суд» (у відповідних відмінках) в абзаці третьому ст. 2, назві розділу III, п. п. 2 і 3 ст. 13, ст. ст. 16, 17, 19, 20, 22-29, п. 1 ст. 30, п. 1 ст. 31, ст. ст. 32, 33, 34 Закону України «Про міжнародний комерційний арбітраж» і замінити його на термін «арбітражний трибунал» (у відповідних відмінках) для позначення тих арбітрів, що безпосередньо вирішують зовнішньоекономічний спір;

в) видалити слова «(третейським судом)» у п. 1 Положення про Міжнародний комерційний арбітражний суд при Торгово-промисловій палаті України, що є Додатком № 1 до Закону України «Про міжнародний комерційний арбітраж», та в П. 1 Положення про Морську арбітражну комісію при Торгово-промисловій палаті України, що є Додатком № 2 до Закону України «Про міжнародний комерційний арбітраж»;

г) провести відповідну заміну термінів в інших нормативно-правових актах України.

1 United Nations General Assembly resolution 40/72 (1985). URL: https://undocs.org/en/A/RES/40/72 (date of reference: 12.08.2019).

2 Про міжнародний комерційний арбітраж: Закон України від 24.02.1994 р. № 4002-XII. База даних «Законодавство Украӥни» / ВР України. URL: http://zakon4.rada.gov.ua/laws/show/4002-12 (дата звернення: 12.08.2019).

3 The Global Competitiveness Report 2018. URL: http://www3.weforum.org/docs/GCR2018/05FullReport/TheGlobalCompeti tivenessReport2018.pdf (date of reference: 12.08.2019).

4 Некрасова Т. Ошибки и ловушки в юридическом переводе: арбитраж. URL: http://www.russian-translators.ru/perevod chesky-opit/law/05/ (дата звернення: 12.08.2019).

5 Положение о государственном арбитраже: постановление Центрального Исполнительного Комитета и Совета Народных Комиссаров от 3 мая 1931 г. № 5/298. Опубликовано в № 124 Известий ЦИК Союза ССР и ВЦИК от 7 мая 1931 г. (С3 СССР 1931 г. № 26, ст. 203). URL: http://istmat.info/node/54776 (дата звернення: 12.08.2019).

6 The USLegal Dictionary. Arbitration. URL: http://administrativelaw.uslegal.com/alternative-means-of-dispute-resolution/arbit ration/ (date of reference: 12.08.2019).

${ }^{7}$ Міжнародне приватне право. Особлива частина: підручник / за ред. професора А.С. Довгерта та професора В.І. Кисіля. URL: http://pidruchniki.com/1728092456831/pravo/mizhnarodniy_komertsiyniy_arbitrazh (дата звернення: 12.08.2019).

8 Про міжнародний комерційний арбітраж: Закон України від 24.02.1994 р. № 4002-XII. База даних «Законодавство Украйни» / ВР України. URL: http://zakon4.rada.gov.ua/laws/show/4002-12 (дата звернення: 12.08.2019).

9 Black's Law Dictionary. Seventh Edition. St. Paul, MN: West Publishing Co., 1999. 1738 p. P. 100.

10 ABA. Dispute resolution processes. Arbitration. URL: https://www.americanbar.org/groups/dispute_resolution/resources/Dis puteResolutionProcesses/arbitration/ (date of reference: 12.08.2019).

${ }^{11}$ Clause (a) Article 2 of UNCITRAL Model Law on International Commercial Arbitration. URL: https://www.jus.uio.no/lm/un. arbitration.model.law.1985/2.html (date of reference: 12.08.2019).

12 Clause (b) Article 2 of UNCITRAL Model Law on International Commercial Arbitration. URL: https://www.jus.uio.no/lm/un. arbitration.model.law.1985/2.html (date of reference: 12.08.2019).

13 Про міжнародний комерційний арбітраж: Закон України від 24.02.1994 р. № 4002-XII. База даних «Законодавство Украйни» / ВР України. URL: http://zakon4.rada.gov.ua/laws/show/4002-12 (дата звернення: 12.08.2019).

14 Article 33 of UNCITRAL Model Law on International Commercial Arbitration. URL: http://www.jus.uio.no/lm/un.arbitration.model.law.1985/33.html (date of reference: 12.08.2019). 
15 Clause (b) Article 2 of UNCITRAL Model Law on International Commercial Arbitration. URL: https://www.jus.uio.no/lm/un. arbitration.model.law.1985/2.html (date of reference: 12.08.2019).

16 Black's Law Dictionary. Seventh Edition. - St. Paul, MN: West Publishing Co., 1999. 1738 p. P. 100.

${ }^{17}$ Latham \& Watkins'. Guide to International Arbitration. URL: https://www.lw.com/thoughtleadership/guide-to-internationalarbitration-2017 (date of reference: 12.08.2019).

18 Міжнародне приватне право. Особлива частина: підручник / за ред. професора А.С. Довгерта та професора В.І. Кисіля. URL: http://pidruchniki.com/1728092456831/pravo/mizhnarodniy_komertsiyniy_arbitrazh (дата звернення: 12.08.2019).

19 Preamble and Clause (a) Article 2 of UNCITRAL Model Law on International Commercial Arbitration. URL: https://www.jus. uio.no/lm/un.arbitration.model.law.1985/2.html (date of reference: 12.08.2019).

20 Про міжнародний комерційний арбітраж: Закон України від 24.02.1994 р. № 4002-XII. База даних «Законодавство України» / ВР України. URL: http://zakon4.rada.gov.ua/laws/show/4002-12 (дата звернення: 12.08.2019).

21 Там само.

22 Там само.

23 Про третейські суди: Закон України від 11.05.2004 р. № 1701-IV. База даних «Законодавство України» / ВР України.

URL: https://zakon.rada.gov.ua/laws/show/1701-15 (дата звернення: 12.08.2019).

24 Там само.

25 Там само.

26 Там само.

27 Щодо практики застосування норм права у випадку колізії: лист Міністерства юстиції України від 26.12.2008 p. № 7580-2-08-19. База даних «Законодавство України» / ВР України. URL: http://zakon4.rada.gov.ua/laws/show/v0758323-08 (дата 3вернення: 12.08.2019).

28 Там само.

29 Про третейські суди: Закон України від 11.05.2004 р. № 1701-IV. База даних «Законодавство України» / ВР України. URL: https://zakon.rada.gov.ua/laws/show/1701-15 (дата звернення: 12.08.2019).

30 Там само.

${ }^{31}$ Convention on the Recognition and Enforcement of Foreign Arbitral Awards. URL: https://www.uncitral.org/pdf/english/texts/ arbitration/NY-conv/New-York-Convention-E.pdf (date of reference: 12.08.2019).

32 Про міжнародні договори України: Закон України від 29.05.2004 p. № 1906-IV. База даних «Законодавство Украӥни» / BР України. URL: https://zakon.rada.gov.ua/laws/show/1906-15 (дата звернення: 12.08.2019).

\section{References:}

United Nations General Assembly resolution 40/72 (1985). URL: https://undocs.org/en/A/RES/40/72 (date of reference: 12.08.2019).

Pro mizhnarodnyj komertsijnyj arbitrazh: Zakon Ukrainy vid 24.02.1994 r. № 4002-XII. Baza danykh «Zakonodavstvo Ukrainy» / VR Ukrainy. URL: http://zakon4.rada.gov.ua/laws/show/4002-12 (data zvernennya: 12.08.2019) [in Ukrainian].

The Global Competitiveness Report 2018. URL: http://www3.weforum.org/docs/GCR2018/05FullReport/TheGlobalCompetitivenessReport2018.pdf (date of reference: 12.08.2019).

Nekrasova, T. Oshybky y lovushky v yurydycheskom perevode: arbytrazh. URL: http://www.russian-translators.ru/perevodchesky-opit/law/05/ (data zvernennya: 12.08.2019) [in Russian].

Polozhenye o hosudarstvennom arbytrazhe: postanovlenye Tsentral'noho Yspolnytel'noho Komyteta y Soveta Narodnykh Komyssarov ot 3 maia 1931 h. № 5/298. Opublykovano v № 124 Yzvestyj TsYK Soiuza SSR y VTsYK ot 7 maia 1931 h. (SZ SSSR 1931 h. № 26, st. 203). URL: http://istmat.info/node/54776 (data zvernennya: 12.08.2019) [in Russian].

The USLegal Dictionary. Arbitration. URL: http://administrativelaw.uslegal.com/alternative-means-of-dispute-resolution/arbitration/ (date of reference: 12.08.2019).

Mizhnarodne pryvatne pravo. Osoblyva chastyna: pidruchnyk / za red. profesora A.S. Dovherta ta profesora V.I. Kysilia. URL: http://pidruchniki.com/1728092456831/pravo/mizhnarodniy_komertsiyniy_arbitrazh (data zvernennya: 12.08.2019) [in Ukrainian].

Black’s Law Dictionary. Seventh Edition // St. Paul, MN: West Publishing Co., 1999. - 1738 p. - P. 100.

ABA. Dispute resolution processes. Arbitration. URL: https://www.americanbar.org/groups/dispute_resolution/resources/DisputeResolutionProcesses/arbitration/ (date of reference: 12.08.2019).

Clause (a) Article 2 of UNCITRAL Model Law on International Commercial Arbitration. URL: https://www.jus.uio.no/lm/un. arbitration.model.law.1985/2.html (date of reference: 12.08.2019).

Article 33 of UNCITRAL Model Law on International Commercial Arbitration. URL: http://www.jus.uio.no/lm/un.arbitration. model.law.1985/33.html (date of reference: 12.08.2019).

Clause (b) Article 2 of UNCITRAL Model Law on International Commercial Arbitration. URL: https://www.jus.uio.no/lm/un. arbitration.model.law.1985/2.html (date of reference: 12.08.2019).

World Heritage Encyclopedia. URL: http://www.worldheritage.org/articles/Arbitral_tribunal (date of reference: 12.08.2019).

Preamble and Clause (a) Article 2 of UNCITRAL Model Law on International Commercial Arbitration. URL: https://www.jus. uio.no/lm/un.arbitration.model.law.1985/2.html (date of reference: 12.08.2019).

Pro tretejs'ki sudy: Zakon Ukrainy vid 11.05.2004 r. № 1701-IV. Baza danykh «Zakonodavstvo Ukrainy» / VR Ukrainy. URL: https://zakon.rada.gov.ua/laws/show/1701-15 (data zvernennya: 12.08.2019) [in Ukrainian].

Schodo praktyky zastosuvannia norm prava u vypadku kolizii: lyst Ministerstva iustytsii Ukrainy vid 26.12.2008 r. № 758-0-208-19. Baza danykh «Zakonodavstvo Ukrainy» / VR Ukrainy. URL: http://zakon4.rada.gov.ua/laws/show/v0758323-08 (data zvernennya: 12.08.2019) [in Ukrainian].

Convention on the Recognition and Enforcement of Foreign Arbitral Awards. URL: https://www.uncitral.org/pdf/english/texts/ arbitration/NY-conv/New-York-Convention-E.pdf (date of reference: 12.08.2019).

Pro mizhnarodni dohovory Ukrainy: Zakon Ukrainy vid 29.05.2004 r. № 1906-IV. Baza danykh «Zakonodavstvo Ukrainy» / VR Ukrainy. URL: https://zakon.rada.gov.ua/laws/show/1906-15 (data zvernennya: 12.08.2019) [in Ukrainian]. 


\section{Резюме}

Петрина В.Н. Термінологічні проблеми в українському законодавстві про міжнародний комерційний арбітраж.

У статті розглянуто проблеми термінології в українському законодавстві про міжнародний комерційний арбітраж. Зокрема, проаналізовано значення таких термінів, як «арбітраж», «третейський суд» та «арбітражний суд», що застосовуються в Законі України «Про міжнародний комерційний арбітраж», та аналізується, як вони співвідносяться з англомовними термінами «arbitration», «arbitral tribunal» та «arbitral institution», що використовуються в Типовому Законі Юнсітрал про міжнародний комерційний арбітраж. У статті також визначено причини невідповідності значення даних українських термінів їх англомовним еквівалентам та запропоновано шляхи гармонізації термінології, що застосовується в Законі України «Про міжнародний комерційний арбітраж», 3 нормами міжнародного права.

Ключові слова: арбітраж, третейський суд, арбітражний трибунал, арбітражна установа, арбітражний суд.

Резюме

\section{Петрина В.Н. Терминологические проблемы в украинском законодательстве о международном коммерческом} арбитраже.

В статье рассмотрены проблемы терминологии в украинском законодательстве о международном коммерческом арбитраже. В частности, анализируется значение таких терминов, как «арбитраж», «третейский суд» и «арбитражный суд», которые используются в Законе Украины «О международном коммерческом арбитраже», и анализируется то, как данные термины соотносятся с такими англоязычными терминами, как «arbitration», «arbitral tribunal» и «arbitral institution», что используются в Типовом Законе Юнситрал о международном коммерческом арбитраже». В статье также определены причины несоответствия значения данных украинских терминов их англоязычным эквивалентам и предложены пути гармонизации терминологии, которая используются в Законе Украины «О международном коммерческом арбитраже», с нормами международного права.

Ключевые слова: арбитраж, третейский суд, арбитражный суд, арбитражный трибунал, арбитражное учреждение, арбитражный суд.

\section{Summary}

Volodymyr Petryna. Terminology problems in Ukrainian legislation on international commercial arbitration.

The terminology problems of Ukrainian legislation on international commercial arbitration are discussed there in this article. Specifically, it is analyzed whether the definition of such Ukrainian term as арбітраж that is used in Ukrainian law as equivalent to the English term arbitration, is defined (understood) in the way that corresponds the definition of the term arbitration in international law. As the result of the analysis it is determined that the Ukrainian term арбітраж is defined in Ukrainian law differently than the equivalent English language term arbitration is defined in international law. In Ukrainian law the term apбimpaж is understood not only as a method of resolution of international commercial disputes, but simultaneously this term means the arbitral institution that administers the arbitration as well as the arbitral tribunal that resolves the dispute. Due to this problem Ukrainian lawyers inadequately understand the notion arbitration used in international law and there may exist real misunderstanding in communication concerning international commercial arbitration between Ukrainian and foreign lawyers.

Another problem discussed in this article concerns the Ukrainian term mpeтейський суд (Treteysky Court) that is used in Ukrainian law to translate into Ukrainian language the English term arbitral tribunal. Meantime, in Ukrainian law the term третейський суд (Treteysky Court) means much more than the English language term arbitral tribunal means in international law. In Ukrainian law the term третейський суд (Treteysky Court) is also used as a synonym of the term apбiтраж (i.e. arbitration). Besides that, the article provides that the definition of the Ukrainian term третейський суд (Treteysky Court) in the Law of Ukraine On International Commercial Arbitration contradicts to the concept of the notion третейський суд (Treteysky Court) as a special body to resolve commercial and civil disputes specified in the Law of Ukraine On Treteysky Courts (ukr. Закон України «Про третейські суди»). Details of the contradiction are specified in the article.

In the article there are determined the reasons of inconsistency of the said Ukrainian notions with the above mentioned notions of international law, and the ways of harmonization of the terminology used in the Law of Ukraine On International Commercial Arbitration with the norms of international law are proposed.

Key words: arbitration, arbitral tribunal, arbitral institution, court of arbitration. 